Maria Korybut-Marciniak

(Uniwersytet Warmińsko-Mazurski w Olsztynie

Instytut Historii i Stosunków Międzynarodowych)

\title{
PRZYCZYNEK DO BADAŃ NAD SLUŻBĄ POLAKÓW Z ZIEM LITEWSKO-BIALORUSKICH W ADMINISTRACJI CYWILNEJ CESARSTWA ROSYJSKIEGO W XIX WIEKU
}

Z biorowość urzędników administracji publicznej Cesarstwa Rosyjskiego na ziemiach polskich wcielonych do Rosji podczas rozbiorów stanowi białą plamę w polskiej historiografii. Grupa administracyjnych pracowników polskiego pochodzenia w strukturach państwa rosyjskiego w XIX stuleciu wydaje się szczególnie interesująca w pryzmacie stosunków społeczno-kulturowych. Przede wszystkim była ona częścią konstytuującej się warstwy inteligencji, częścią traktowaną „po macoszemu” przez badaczy społeczeństwa ziem litewsko-białoruskich. W guberniach północno-zachodnich formująca się „,klassa umysłowa" była w szczególnie trudnej sytuacji. Już prześledzenie losów absolwentów Uniwersytetu Wileńskiego pokazuje, że była to „inteligencja bez wyjścia” - zdobyte przez nią kwalifikacje okazały się społeczeństwu zbędne'. Po 1831 roku wykształceni Polacy mieli jeszcze bardziej ograniczone możliwości utrzymania się z pracy umysłowej. Zapóźnienie cywilizacyjne tych ziem w porównaniu z Europą Zachodnią pogłębiało się. Okres międzypowstaniowy charakteryzował się stopniowym hamowaniem rozwoju polskiej kultury, ograniczeniem języka polskiego w oświacie i administracji, zamknięciem reliktów po Uniwersytecie Wileńskim - Akademii Medyko-Chirurgicznej i przeniesieniem do Petersburga Akademii Duchownej (1842), wzmożeniem cenzury wobec inicjatyw wydawniczych i czasopiśmienniczych, zwiększoną kontrolą ruchu księgarskiego. Obok luminarzy kultury, niestrudzenie podejmujących wysiłki na polu edukacyjnym, wydawniczym, księgarskim i organizacyjnym, którzy znaleźli się w kręgu zainteresowań historyków ${ }^{2}$, istniała rzesza Polaków, o których nie pamięta się. Grupa ludzi wykształconych, która stawała w obliczu trudnych realiów codzienności,

${ }^{1}$ D. Beauvois, Inteligencja bez wyjścia (1803-1832), [w:] Inteligencja polska pod zaborami, red. R. Czapulis-Rastenis, Warszawa 1978, s. 12-64.

${ }^{2}$ M. Stolzman, Nigdy od ciebie miasto... Dzieje kultury wileńskiej lat międzypowstaniowych (1832-1863), Olsztyn 1987; L. Zasztowt, Kresy 1832-1864, Szkolnictwo polskie na ziemiach litewsko-ruskich dawnej Rzeczpospolitej, Warszawa 1997. 
trudnych realiów gospodarczych, i trudnych realiów polityki zaborczej. Czasami opuszczali oni miejsce swojego zamieszkania i za chlebem wyruszali albo na Wschód - zasilić liczną kolonię polską nad Newą, albo na Zachód - do Królestwa Polskiego, a niekiedy dalej, przyłączyć się do jeszcze liczniejszej grupy Polaków-emigrantów (robiąc niejednokrotnie błyskotliwe kariery) ${ }^{3}$. Większość nie decydowała się na opuszczenie rodzinnej ziemi. Ludzie ci usiłowali znaleźć swoje miejsce w społeczeństwie. Część podejmowała decyzję o zatrudnieniu w carskim systemie administracyjnym

Funkcjonuje stereotyp, że ci, którzy podjęli służbę państwową w Imperium Rosyjskim z „urzędu” stawali w pozycji lojalistycznej - musieli być przecież dyspozycyjni wobec państwa - państwa zaborczego. Na ile ów lojalizm wiązał się z przyjęciem obcej kultury?, czy podjęcie posady urzędnika było równoznaczne ze zgodą na zaistniały stan polityczny?, jaki był stosunek Polaków-urzędników do społeczności, wobec której wykonywali swoje służbowe obowiązki?, gdzie kończyła się granica służby zaborcy i czy taką granicę można wyznaczyć?, czy urzędnik Polak był traktowany na równi z urzędnikiem państwa zaborczego?, czy występował ostracyzm wobec osób wchodzących do rosyjskiej służby cywilnej w polskich środowiskach patriotycznych?, czy Polacy - urzędnicy wnikali do środowisk rosyjskich?, jak przedstawiały się stosunki z Rosjanami?, jaki był ich stosunek do powstań narodowo-wyzwoleńczych? Te i wiele innych pytań ciągle oczekuje na odpowiedź.

$\mathrm{Na}$ wstępie warto doprecyzować zagadnienia pojęciowe związane z zakresem tematycznym artykułu. Urzędnik to pojęcie bardzo szerokie, zachowujące dużą płynność - zmieniające się w zależności od miejsca i czasu ${ }^{4}$ Urzędnikiem (czynownikiem) cywilnym w Cesarstwie Rosyjskim był funkcjonariusz państwowy - osoba posiadająca pełnomocnictwo służbowe wchodzące w zakres zarządu państwowego, podporządkowana systemowi hierarchii służbowej ustanowionej przez Piotra I - czternastostopniowej „Tabeli o rangach”. Tabela rang obowiązywała do upadku Rosji carskiej, wielokrotnie ulegając modyfikacjom (kwalifikacje urzędnika zmieniały pozycję rangową) $)^{5}$. Do cywilnych urzędników państwowych od 1812 roku zaliczano zarówno nauczycieli, profesorów uniwersyteckich, absolwentów uniwersytetów ${ }^{6}$, pracowników muzealnych, bibliotekarzy, lekarzy, inżynierów, policjantów miejskich, duchownych etc. jak i pracowników ministerstw,

\footnotetext{
${ }^{3}$ D. Beauvois, Szkolnictwo polskie na ziemiach litewsko-ruskich 1803-1832, t. 1, Uniwersytet Wileński, Lublin 1991, s. 338.

${ }^{4}$ Trudności metodologiczne związane z określeniem pojęcia urzędnik podejmuje Zbigniew Naworski; zob.: Z. Naworski: Stużba publiczna od monarchii absolutnej po czasy współczesne, [w:] Dzieje biurokracji, red. A Górak, K. Latawiec, D. Magier, t. 4, Lublin-Siedlce 2011, s. 13-16.

${ }^{5}$ Zob. szerz. Л.Е. Шепелев, Чиновный мир России ХVII - иачало XX в., Sankt Petersburg 1999, s. 131-157.

${ }^{6}$ Tytuł „student” przysługiwał osobie, która ukończyła podstawowy kurs studiów i pomyślnie zdała egzaminy - dawał on uprawnienie do zaszeregowania w XIV klasie tabeli rang. Tytuł „kandy-
} 
urzędników gubernialnych i powiatowych, sędziów i prokuratorów - wszyscy oni otrzymywali odpowiednią rangę i klasę, przyznawano im nagrody i odznaczenia, wyznaczano emerytury i zobowiązywano do noszenia mundurów ${ }^{7}$. Pełnione stanowiska urzędowe nie zawsze odpowiadały rangom. Prawo posługiwania się rangą przysługiwało nawet wówczas, jeżeli urzędnik zajmował posadę poniżej „stanowiska rangowego". O przedstawieniu do rangi decydowali jego zwierzchnicy po spełnieniu przez urzędnika odpowiednich warunków (wysługa lat pracy lub egzamin kwalifikacyjny). Tytulatura rangowa przysługiwała również urzędnikowi po przejściu na emeryturę. Całość przepisów dotyczących służby państwowej w 1837 roku została zamieszczona w III tomie Zbioru Praw Cesarstwa Rosyjskiego pod nazwą Ustawy o stużbie cywilnej (tę również wielokrotnie uzupełniano i nowelizowano) $)^{8}$. W objaśnieniach do trzeciej części Dziadów Adam Mickiewicz daje następującą, bardzo trafną charakterystykę pojęcia „,czynownik”:

\begin{abstract}
Wyrazy czyn, czynownik, często sa tu użyte $w$ znaczeniu rosyjskim, dla Litwinów tylko zrozumiałe. W Rosji, ażeby nie być chtopem albo kupcem, słowem, aby mieć przywilej uwalniajacy od kary knuta, trzeba wejść w stużbę rzadowa i pozyskać tak nazwana klase albo czyn. Stużba dzieli się na czternaście klas; potrzeba kilka lat stużby dla przejścia z jednej klasy $w$ drugą. Sa przepisane czynownikom różne egzamina, podobne do formalności zachowujacych się $w$ hierarchii mandaryńskiej $w$ Chinach, skąd, zdaje się, że ten wyraz Mogołowie do Rosji przenieśli, a Piotr Pierwszy znaczenie tego wyrazu odgadną i cata instytucję $w$ duchu prawdziwie chińskim rozwinat. Czynownik często nie jest urzędnikiem, czeka tylko urzędu i starać się on ma prawo. Każda klasa albo czyn odpowiada pewnej randze wojskowej, i tak: doktor filozofii albo medycyny liczy się w klasie ósmej i ma stopień majora, czyli asesora koleskiego; stopień kapitański ma frejlina, czyli panna dworu cesarskiego; biskup lub archirej jest jenerałem. Między czynownikami wyższymi i niższymi stosunki uległości i postuszeństwa przestrzegają się z równa prawie ścisłościa jak w wojsku.
\end{abstract}

W niniejszych rozważaniach będę traktowała urzędnika w rozumieniu węższym - jako osobę posiadającą odpowiednie kwalifikacje i zajmującą stanowisko służbowe w aparacie administracyjnym państwa rosyjskiego. W XIX-wiecznych źródłach pojawia się termin „biuralista” - oznaczający urzędnika zatrudnionego na etacie w konkretnym urzędzie, którego praca opierała się na sporządzaniu oficjalnych dokumentów - zarządzeń, sprawozdań, korespondencji, wyroków itd., zatwierdzanych przez zwierzchników danej jednostki administracyjnej. Współcześnie termin ten ma zupełnie inną pojemność znaczeniową ${ }^{10}$. Natomiast

data" otrzymywała osoba po ukończeniu kursu studiów zakończonego celującym zdaniem egzaminów (XIII klasa w tabeli rang). Tytuł magistra w hierarchii cywilnej dawał IX klasę, zaś doktora VII klasę.

7 Л.Е. Шепелев, dz. cyt., s. 116.

${ }^{8}$ K. Koranyi, Powszechna historia państwa i prawa, Warszawa 1966, t. 3, s. 387.

${ }^{9}$ A. Mickiewicz, Dziady, t. 2, Paryż 1844, s. 131 [objaśnienia poety].

${ }^{10}$ Biuralista potocznie oznacza osobę kierującą się w wykonywaniu swojej pracy zawodowej wyłącznie przepisami. 
XIX-wieczne rozumienie tego terminu najlepiej odpowiadałby zakresowi poniższych rozważań.

W dotychczasowych badaniach nad społeczeństwem polskim w epoce porozbiorowej Polacy, którzy zasilili struktury administracyjne Rosji, Austrii i Prus, zajmują nadal marginalne miejsce. Monografii podejmujących problematykę warstwy urzędników na ziemiach polskich w XIX stuleciu jest niewiele ${ }^{11}$, natomiast artykuły mają najczęściej charakter analityczny i dotyczą zwykle konkretnych urzędów (głównie wyższych) w wybranej jednostce administracyjnej ${ }^{12}$. O ile tematyki grupy urzędników cywilnych - Polaków w guberniach zachodnich Cesarstwa Rosyjskiego do tej pory prawie zupełnie nie podejmowano - ewentualnie pojawiała się ona w ramach szerszych badań na zjawiskiem korupcji w Rosji lub postawami serwilistycznymi wobec caratu ${ }^{13}$, to nieco większym zainteresowaniem cieszyły się kadry urzędnicze Księstwa Warszawskiego ${ }^{14}$ i Królestwa Polskiego ${ }^{15}$. Urzędnicy guberni zachodnich Cesarstwa Rosyjskiego jako grupa

${ }^{11} \mathrm{~W}$ ostatnim czasie ukazała się wieloautorska dwutomowa monografia: Między irredenta a kolaboracja. Ugoda, lojalizm i legalizm. „Dusza urzędnika” - zewnętrzna akceptacja $i$ wewnętrzna niezgoda?, red. N. Kasparek i M. Klempert, Olsztyn 2015; Między irredentą a kolaboracją. Ukoda, lojalizm, legalizm. „Dusza urzędnika” - ludzie i ich kariery, red. A. Szmyt, Olsztyn 2015.

${ }^{12} \mathrm{~W}$ zakresie urzędników pruskich należy wymienić książkę Z. Zielińskiego, Wyżsi urzędnicy pruskiej administracji prowincjonalnej w Poznańskiem 1871-1918, Poznań 2014.

${ }^{13}$ A. Chwalba, Imperium korupcji w Rosji i Królestwie Polskim w latach 1861-1917, Warszawa 2001; tenże, Polacy w stużbie Moskali, Warszawa 1999.

${ }^{14}$ W. Rostocki, Korpus w gęsie pióra uzbrojony. Urzędnicy warszawscy, ich życie i praca w Księstwie Warszawskim i Królestwie Polskim do roku 1831, Warszawa 1972; T. Knopp, Prefekci Księstwa Warszawskiego. Przyczynek do portretu zbiorowego, „Studia Historyczne” 2012, R. 55, z. 3-4, s. 357-370, P. K. Marszałek, Gubernatorzy wojskowi w systemie polskiej administracji początków XIX wieku, „Czasopismo Prawno-Historyczne” 2012, t. 64, z. 1, s. 39-65; P. Cichoń, Korpus urzędniczy w myśli administracyjnej Księstwa Warszawskiego 1807-1815, „Krakowskie Studia z Historii Państwa i Prawa" 2004, s. 147-172.

15 J. Szczepański, Urzędnicy administracji państwowej Królestwa Polskiego w latach 18151866, Kielce 2015; T. Suma, Urzędnicy poczty Królestwa Polskiego w latach 1815-1866: próba charakterystyki zbiorowości, Warszawa 2008; W. Caban, Urzędnicy administracji państwowej a powstanie styczniowe (na przykładzie guberni radomskiej), [w:] Inteligencja polska XIX i XX wieku, t. 5, red. R. Czepulis-Rastenis, Warszawa 1987, s. 145-172; tenże, Inteligencja prowincjonalna wobec walki o niepodległość w XIX wieku na przykładzie urzędników administracji państwowej Guberni Radomskiej, [w:] Polska w XIX i XX wieku, Spoleczeństwo i gospodarka, red. W. Caban, J. Szczepański, Kielce 2013, s. 111-122; K. Latawiec, Urzędnicy pochodzacy z guberni białoruskich w korpusie cywilnej administracji ogólnej Królestwa Polskiego na przełomie XIX i XX w. Przyczynek do badań nad inteligencja urzędnicza w imperium rosyjskim, [w:] Дыяспара.Культуралогія. Гісторыя, пад рэд. А. Мальдзіса, А. Смаленчука, Минск 2006, s. 296-303; tenże, Naczelnicy powiatów guberni lubelskiej w latach 1867-1915. Próba charakterystyki grupy, „Annales UMCS”, sectio F, vol. LVIII, 2003, s. 73-96; tenże, Obsada personalna chetmskiego zarzadu powiatowego w latach 1867-1915, „Rocznik Chełmski”, t. 10, 2006, s. 117-160; G. Smyk, Zasady funkcjonowania rosyjskiego modelu biurokratycznego w Królestwie Polskim po powstaniu styczniowym, „Studia z Dziejów Państwa i Prawa Polskiego" 2006, nr 2, s. 407-414; tenże, Administracja publiczna Królestwa Polskiego w latach 1864-1915, Lublin 2011; S. Wiech, Warszawscy generałowie-guber- 
społeczna, formująca się inteligencja, pozostali w niszy, stereotypowo traktowani jako służalcy Rosji nieuchronnie ,skazani na rusyfikację” w przeciwieństwie do irredentystów, których reperkusje popowstaniowe rzucały na wschód na daleką Syberię lub w przeciwnym kierunku - na emigrację, dozgonną tułaczkę. Wszystkich pracowników rosyjskiej administracji publicznej, którzy pozostali na ziemiach dawnego Wielkiego Księstwa Litewskiego i usiłowali poradzić sobie w sytuacji wzmożonych represji skłonni jesteśmy widzieć jako serwilistów, lojalistów, pozbawionych uczuć narodowych, wyrzekających się polskich tradycji wykonawców poleceń rosyjskich zwierzchników albo traktować na równi z urzędnikami rosyjskimi. Wstępne badania wykazują, że tkanka grupy urzędniczej na ziemiach litewsko-białoruskich, której trzon do powstania styczniowego stanowili Polacy, była bardzo zróżnicowana - zarówno jeżeli chodzi o pobudki podjęcia służby, poziom wykształcenia, status materialny, stosunek do wykonywanego zawodu, a także postawę wobec zrywów narodowych, poglądy polityczne, poczucie tożsamości narodowej.

Niedostatek badań nad urzędnikami w strukturach państw zaborczych można argumentować nie tyle ograniczeniami w dostępie do źródeł, co raczej ich charakterem. O ile arystokracja i ziemiaństwo pozostawiły po sobie stosunkowo dużą ilość dokumentacji, poczynając od memuarów, poprzez korespondencję, materiały o charakterze statystyczno-gospodarczym itp., które zachowały się w archiwach prywatnych; urzędnicy - choć sami pracowali piórem, rzadko za pióro chwytali, by udokumentować własne losy, podzielić się swoimi przemyśleniami i spostrzeżeniami. Podstawę do badań nad urzędnikami „Kraju Zachodniego” stanowią w pierwszej kolejności źródła masowe o charakterze indywidualnym - akta osobowe poszczególnych pionów administracyjnych (gubernialnej, powiatowej i miejskiej). Formularnyje spiski stanowią oficjalną dokumentację wytworzoną przez daną jednostkę administracyjną dla każdego urzędnika. Obok przebiegu służby cywilnej dają informacje na temat pochodzenia, wykształcenia, konfesji, stanu cywilnego, średniej wieku, liczby potomstwa, zarobków, majątku nieruchomego. Stanowią więc źródło umożliwiające stworzenie zarysu struktury

natorzy o sytuacji społeczno-politycznej Królestwa Polskiego. Raporty Albiedynskiego i Szuwałowa z lat 1881 i 1896, oprac. Stanisław Wiech, Kielce 2007; tenże, Lustracje urzędników administracji państwowej Królestwa Polskiego w latach 1866-1873, [w:] Między irredenta a kolaboracją. Polacy w czas zaborów wobec obcych władz i systemów politycznych, red. S. Kalembka i N. Kasparek, Olsztyn 2001; tenże, Urząd generat-gubernatora w Rosji $i$ w Królestwie Polskim, „Czasopismo Prawno-Historyczne”, t. 59, 2007, z. 1, s. 51-86; tenże, Między pragmatyzmem a serwilizmem. Charakterystyka postaw i zachowań urzędników Królestwa Polskiego po upadku powstania styczniowego w ocenie carskiej policji politycznej, [w:] Między irredenta a kolaboracja. Postawy spoleczeństwa polskiego w latach niewoli - „W obcym mundurze”, red. L. Michalska-Bracha i M. Korybut-Marciniak, Warszawa 2013, s. 199-210; J. Żywicki, Urzędnicy - architekci, budowniczowie, inżynierowie cywilni...: ludzie architektury i budownictwa $w$ województwie lubelskim oraz guberni lubelskiej w Królestwie Polskim w latach 1815-1915, Lublin 2010; M. Osiecka, Urzędnicy Komisji Rządowych Królestwa Polskiego 1815-1867, „Miscellanea Historico-Archivistica” 2014, t. 21, s. 171-196. 
środowiska urzędników różnych szczebli administracyjnych i określenia głównych jej cech. Na ich podstawie nie możemy jednak zarysować obrazu „mentalności” grupy. Te najliczniejsze dokumenty nie dadzą odpowiedzi na pytania odnośnie tożsamości narodowej, poglądów politycznych, postawy wobec zrywów narodowych. Dodatkowym utrudnieniem dla badaczy jest rozproszenie tych źródeł. Zachowane akta osobowe znajdują się w obrębie często obszernych zespołów archiwalnych poszczególnych urzędów. Akta osobowe są rozproszone nie tylko w wielu zespołach archiwalnych (często również w obrębie zespołu), ale również w wielu archiwach litewskich, białoruskich, polskich i rosyjskich.

Do źródeł umożliwiających prześledzenie zmian w administracji urzędów posłużyć mogą również Pamjatnyje kniżki - Książki pamiątkowe tworzone dla poszczególnych guberni. Są to urzędowe prowincjonalne wydawnictwa informacyjne, drukowane w osiemdziesięciu ośmiu guberniach i obwodach Cesarstwa Rosyjskiego. Początek tych publikacji przypada na rok 1833, wydawane były do roku 1917. Od połowy lat czterdziestych wydawnictwo objęło gubernie północno-zachodnie - w guberni wileńskiej ukazywało się w latach 1845-1915, w guberni mińskiej w latach 1845-1917, w guberni kowieńskiej w latach 1845-1915, w guberni mohylewskiej w latach 1845-1914. Publikacje miały formę rocznego sprawozdania władz gubernialnych dotyczącego danej guberni. Zawierają one między innymi kalendarz adresowy, czyli wykaz wszystkich rządowych instytucji gubernialnych i powiatowych z ich składem osobowym. Szczególnie cenne dla badań nad grupą urzędników składy osobowe poszczególnych urzędów, dają możliwość prześledzenia zmian personalnych (również narodowościowych) w poszczególnych urzędach.

Do ciekawych materiałów, które dają szerszy ogląd grupy należą akta śledztw administracyjnych - materiał bardzo obfity, ale jednocześnie dający bogate informacje odnośnie „moralności” urzędników, ich warunków egzystencjalnych, dające możliwość określenia roli urzędnika w relacji pomiędzy władzą a społeczeństwem. $\mathrm{Na}$ ten rodzaj akt zwrócił uwagę Jerzy Szczepański badając urzędników guberni radomskiej ${ }^{16}$. W guberniach północno-zachodnich ten rodzaj dokumentacji trzeba jednak traktować z bardzo dużą ostrożnością - urzędnicy polskiego pochodzenia z pewnością byli na tych terenach traktowani ze zdecydowanie większą surowością niż w Królestwie Polskim, a nadużycia ,administracyjne” mogły stanowić przykrywkę do ukarania pracownika za nieprawomyślność polityczną.

Materiały, które warte są prześledzenia to również dyplomy legitymacyjne wydawane przez Heroldię Cesarstwa Rosyjskiego oraz akta dowodowe dołączane do podań o prawo szlachectwa. W systemie uprzywilejowania stanu szlacheckiego w Rosji tytuł szlachecki miał istotne znaczenie również dla urzędników - dawał pierwszeństwo jego członkom do awansu w służbie cywilnej ${ }^{17}$. Legitymacja szla-

${ }^{16}$ J. Szczepański, $d z$. cyt.

${ }^{17}$ J. Sikorska-Kulesza, Deklasacja drobnej szlachty na Litwie i Białorusi w XIX wieku, Warszawa 1995, s. 19. 
checka umożliwiała wstępującemu do służby szybki awans do X klasy (do rangi sekretarza kolegialnego). Wielu Polaków rozpoczynających karierę w administracji cywilnej przesyłało dokumenty do Heroldii w celu starania się o prawo do szlachectwa. Akta Heroldii Cesarstwa Rosyjskiego znajdują się przede wszystkim w Rosyjskim Państwowym Archiwum Historycznym w Petersburgu.

Obok źródeł proweniencji urzędowej można również spotkać wyjątkowe przykłady źródeł o charakterze osobistym - pamiętniki i korespondencję prywatną urzędników. Ta jednak ma charakter unikatowy - przedstawiciele tej grupy rzadko podejmowali się spisywania memuarów. Istotny materiał źródłowy o charakterze uzupełniającym stanowi prasa - zwłaszcza jeśli chodzi o wyższe stanowiska urzędowe. W prasie petersburskiej, a także w periodykach wydawanych w guberniach zachodnich informowano o nominacjach tytularnych urzędników zdobywających nowe rangi, pojawiały się też wzmianki o zmianach personalnych na poszczególnych stanowiskach, a także nekrologi urzędników szczególnie zasłużonych. Także uzupełniający charakter będą miały źródła literackie. Wątek „urzędniczy” w dziewiętnastowiecznej literaturze pięknej - polskiej i rosyjskiej - jest jednak wyraźnie zaznaczony i stanowi istotny element w odtworzeniu obrazu życia prywatnego, postawy politycznej, warunków egzystencjalnych, uwarunkowań służby cywilnej, percepcji grupy w oczach społeczeństwa polskiego i rosyjskiego, a także stosunków polsko-rosyjskich.

\section{$* * *$}

Stosunek Polaków do służby cywilnej w Rosji zmieniał się w zależności od sytuacji politycznej. Podobnie ewoluowały poglądy władzy i społeczeństwa rosyjskiego w odniesieniu do obecności Polaków w służbie urzędniczej imperium ${ }^{18}$. W I połowie XIX wieku podejmujący pracę w urzędach aparatu administracyjnego Rosji to przedstawicie przede wszystkim uboższej części nobilitas (czynszowej, zagrodowej i okolicznej szlachty) ${ }^{19}$, synowie zubożałych rodzin szlacheckich (często absolwenci Cesarskiego Uniwersytetu Wileńskiego), w znikomym procencie mieszczanie. Wykształceni Polacy, których okoliczności ekonomiczne zmuszały do szukania innych źródeł dochodu niż gospodarowanie majątkiem znajdowali możliwość zatrudnienia w służbie państwowej. W pierwszym dwudziestopięcioleciu wieku XIX podjęcie pracy urzędowej nie miało raczej negatywnych konotacji politycznych, tym bardziej, że językiem urzędowym pozostawał język polski, kadry urzędnicze składały się w większości z Polaków. Trzeba jednak brać pod uwagę opory społeczeństwa, które miało obawy przed wejściem w kompromis z mocarstwem zaborczym. W kręgach szlacheckich służba cywilna była postrzegana jako zgoda na integrację z Rosją.

18 Л. Е. Горизонтов, Служить или не служить империи? Поляки в России ХІХ в., [w:] Rosyjsko-polskie kontakty językowe, literackie i kulturalne, red. W. Choriew, M. Wołos, Moskwa 2011, s. 298-307.

${ }^{19}$ Takie nazwy kategorii drobnej szlachty występowały w oficjalnych dokumentach do 1831 roku. 
Aleksander I po reformach administracyjnych w 1802 roku - które likwidowały kolegia ustanawiając osiem ministerstw - miał ogromny problem z kadrą urzędniczą. Rosły potrzeby biurokratyczne państwa, a kadra urzędnicza pod względem wykształcenia pozostawiała wiele do życzenia. W 1809 roku Michał Sperański przygotował ukaz dotyczący zasad wstępowania do cywilnej służby państwowej i wymagań odnośnie zdobywania wyższych rang (od klasy VIII), których podstawą miało być wyższe wykształcenie lub zdanie egzaminu o ustalonym programie ${ }^{20}$. Reakcyjne rządy Mikołaja I nie obyły się bez reform odnośnie kadry urzędników cywilnych. Car był również przekonany, że urzędników w Cesarstwie jest nadmiar i stąd rekrutację do służby cywilnej postanowił ograniczyć. W 1827 roku wprowadził ukaz o kancelaryjnych pracownikach służby cywilnej zabraniając przyjmowania kupców, osób karanych, mieszczan, obcokrajowców, byłych wojskowych, duchownych, służących. Wszystkich urzędników podzielił na 4 stany - według pochodzenia - tylko osoby pochodzenia szlacheckiego mogły dosłużyć się wyższych rang i tytułów ${ }^{21}$.

Motywy podejmowania zatrudnienia w urzędach przez mieszkańców ziem litewsko-białoruskich były różne. Najczęściej była to konieczność podtrzymania egzystencji, rzadziej chęć zrobienia kariery. Dla niektórych przedstawicieli szlachty był to sposób na zdobycie „lekkiego chleba”. Należy podkreślić fakt, że wykształceni mieszkańcy ziem dawnego Wielkiego Księstwa Litewskiego nie mieli wielu możliwości zawodowych, zwłaszcza od przejęcia rządów przez Mikołaja I. Absolwenci litewskich gimnazjów, a także Uniwersytetu Wileńskiego po ukończeniu nauki częstokroć przez trudną sytuację egzystencjalną byli zmuszeni do podjęcia jakiegokolwiek zatrudnienia. Rozrastający się rosyjski aparat biurokratyczny w pierwszej połowie stulecia wykazywał ciągłe niedobory personalne i chętnie wchłaniał grupę wykształconych młodych mieszkańców ziem litewskich. Dla wielu była to praca doraźna, dająca możliwość przetrwania trudnego czasu, zwłaszcza w sytuacji, gdy rodzina znajdowała się na granicy pauperyzmu. Młodzi ludzie po ukończeniu nauki w gimnazjum mogli podjąć pracę w kancelarii, odciążyć nieco rodzinny budżet opierający się na dochodach z niewielkiego majątku lub dzierżawy. Taka posada, choć mało płatna, zwłaszcza w okresie pierwszych lat służby, gwarantowała stałe zarobki i zaspakajała podstawowe potrzeby. Część młodzieży upatrywała w niej szansę na rozwijanie własnych zdolności, planowała systematyczne wspinanie się po szczeblach ,tabeli rang”, niejednokrotnie za cel stawiała sobie służbę w Petersburgu. Większość jednak uznawała ten rodzaj zatrudnienia za konieczność. Czasami podjęcie pracy w urzędzie było spowodowane brakiem funduszy na dalsze kształcenie - młodzież próbowała w ten sposób zarobić na studia.

\footnotetext{
20 Л.Е. Шепелев, $d z . c y t .$, s. 114.

${ }^{21}$ Tamże, s. 117-118.
} 
W okresie międzypowstaniowym rekrutacja do służby cywilnej nadal skierowana była na Polaków, ponieważ Rosjanie pracę na zachodnich rubieżach Cesarstwa traktowali jak ,zesłanie”. Przeglądając formularnyje spiski pracowników kancelarii wileńskiego generał-gubernatora z lat 1845-1860 dostrzegamy, że znakomitą większość obsady stanowią katolicy szlacheckiego pochodzenia ${ }^{22}$. W przypadku większości urzędników wstąpienie do służby cywilnej datuje się na lata 1813-1831. Jest też część, która podejmuje służbę w dobie popowstaniowej (tu mamy liczne przypadki byłych wojskowych, którzy zakończyli służbę w wojsku carskim). Służba cywilna osób narodowości polskiej/wyznawców religii rzymskokatolickiej była w tym okresie już utrudniona. W latach trzydziestych zmienił się charakter pracy urzędnika. Za czasów mikołajewskich, w 1832 roku sformułowane zostały „Prawa zasadnicze Cesarstwa Rosyjskiego”, które realizowały zasadę legalizmu działania całego aparatu państwowego. Zgodnie z nimi wszystkie organy państwowe miały działać w ramach prawa pochodzącego wyłącznie od monarchy $^{23}$. Brak jakichkolwiek instytucji kontrolujących funkcjonowanie administracji państwowej prowadziło do jej upolitycznienia. Pracownik administracji cywilnej zyskał nowy wymiar, tak jak cała rosyjska administracja, której kierunek i zakres działania był dostosowywany do aktualnych preferencji politycznych państwa, a nie potrzeb obywateli ${ }^{24}$. W „Kraju Zachodnim” dodatkowym elementem, który pejoratywnie cechował pracowników służby cywilnej było powstanie listopadowe i związane z nim represje wobec Polaków. Ten sam urzędnik - wykonawca woli monarchy, który jeszcze $\mathrm{w}$ dobie przedpowstaniowej nie podlegał jednoznacznemu napiętnowaniu przez wykonywanie zawodu, w dobie popowstaniowej był postrzegany zupełnie inaczej. Wobec krzywd doznanych przez żywioł polski zajmował miejsce po drugiej stronie barykady - stawał się w opinii społecznej wrogiem polskości, lojalistą, rosyjskim pachołkiem. Wykonując dyspozycje przełożonych w scentralizowanym systemie władzy - już nie tylko przestał służyć obywatelom, ale występował przeciwko nim egzekwując dotkliwe ograniczenia i kary. Doba międzypowstaniowa przyniosła chyba najdotkliwsze „rozdarcie duszy” Polaka - urzędnika. Najczęściej nie wyrażał on sprzeciwu wobec zaistniałej sytuacji, częstokroć będąc zatrudniony przez wiele lat na etacie kancelaryjnym nie wyobrażał sobie zmiany zawodu i porzucenia stałej pracy. Powodowany lękiem o utratę stanowiska i jednocześnie świadomy carskiego kursu politycznego skierowanego przeciw Polakom znajdował się na rozdrożu.

Powstanie listopadowe spowodowało również rozróżnienie prawne pomiędzy urzędnikami „guberni centralnych” a urzędnikami „guberni zachodnich”. Ci ostatni mieli utrudniony dostęp do wyższych rang, a także do kariery w stolicy Rosji. Nieufność Mikołaja I wobec drobnej szlachty, w której upatrywał wichrzy-

\footnotetext{
${ }^{22}$ Lietuvos Valstybès Istorijos Archyvas, f. 378, inw. 131.

${ }^{23}$ W. Śliwowska, Mikołaj I i jego czasy (1825-1856), Warszawa 1865, s. 33-36.

${ }^{24} \mathrm{G}$. Smyk, Zasady funkcjonowania rosyjskiego ...., s. 411.
} 
cieli porządku politycznego, element niebezpieczny i nieobliczalny odbiła się nie tylko we wzmożonej akcji legitymacyjnej ${ }^{25}$. Ograniczenia dotyczyły również karier urzędniczych. Już od 1831 roku mieszkańcy „Kraju Zachodniego” nie mogli udać się na służbę do Petersburga bez specjalnego zezwolenia cara ${ }^{26}$. Imperator rosyjski w 1837 roku podpisał ustawę, zgodnie z którą mieszkańcom guberni zachodnich Imperium Rosyjskiego, z wyjątkiem wyznawców prawosławia i grekokatolików, zabraniano zajmowania stanowisk w ministerstwach i w głównych urzędach w petersburskiej guberni, zanim nie odbędą pięcioletniej służby w guberniach wielkorosyjskich ${ }^{27}$. W 1840 roku wprowadzono ustawę zezwalającą mieszkańcom guberni zachodnich wstępowanie do państwowej służby wyłącznie za zgodą Komisji Rewizyjnej. Warunkiem uzyskania zgody na pełnienie służby cywilnej było udowodnienie przed taką komisją swojego szlacheckiego pochodzenia. Dodatkowo musiano udowodnić, że ojcowie i dziadowie osoby ubiegającej się o możliwość wstąpienia do służby, przed wejściem w życie ustawy z 1831 roku posiadali majątki ${ }^{28}$. W 1841 roku wszedł w życie ukaz dotyczący służby cywilnej potomków katolików z terenów guberni zachodnich - mieli oni być zatrudniani w miejscach innych niż miejsce ich urodzenia ${ }^{29}$. Zaciskający się na Polakach powróz ustaw mikołajewskich był coraz dotkliwszy, a urzędnicza egzystencja coraz trudniejsza. Niewielu jednak decydowało się na zmianę konfesji - pojedyncze przypadki można odnotować pośród urzędników wyższych rangą. Warto zaznaczyć, że w okresie międzypowstaniowym marzeniem wielu „,biuralistów" z guberni północno-zachodnich było znalezienie zatrudnienia w głębi Rosji, co otwierało szansę na szybszy awans, wyższe wynagrodzenie i dawało poczucie większej stabilizacji. Urzędnicy - Polacy pozostający na Kresach byli narażeni na ciągłe podejrzenia, frustracje związane z zamykaniem możliwości awansu, a także niższymi niż Rosjanie wynagrodzeniami. Poza tym nie byli dopuszczani do wyższych urzędów - ich kariery hamowano, na jednym stanowisku, bez podwyżki płacy urzędnik musiał pracować przez długie lata. Niewielkiej części „urzędniczej braci" udało się jeszcze przed powstaniem znaleźć miejsce w guberniach wielkorosyjskich i w stolicy. Zdobycie posady w głębi Rosji, zwłaszcza w Petersburgu, wymagało specjalnych protekcji, często wiązało się ze sporym wysiłkiem finansowym na początku służby (koszty podróży, kwaterunku, wyżywienia, odzieży). Było jednak gwarancją szybszej kariery, otwierało możliwości na otrzymanie nagród i odznaczeń, dawało stabilizację finansową.

${ }^{25}$ J. Sikorska-Kulesza, dz. cyt., s. 30-45.

${ }^{26}$ Л. Е. Горизонтов, Парадоксы имперской политики: поляки в России и русские в Польше, Москва 1999, s. 42.

${ }^{27}$ Полное собрание законов Российской Империи, 2-е собрание, t. 12, 1837 r., $\mathrm{nr} 9894$.

${ }^{28}$ Tamże, t. 15, 1840 r., nr 13047.

${ }^{29}$ Tamże, t. 16, 1841 r., nr 114182. 
Najtrudniejszy okres dla urzędników - katolików na ziemiach litewsko-białoruskich miał miejsce po wybuchu powstania styczniowego. Michaił Murawjow przybyły do Wilna w maju 1863 roku, jako jedno ze swoich priorytetowych zadań postawił zmianę składu osobowego aparatu administracyjnego przez zastąpienie urzędników „tutejszych” urzędnikami z centralnych guberni rosyjskich. 23 października (4 listopada) polecił, by wszystkie stanowiska policyjne i urzędy wyższe zajmowali wyłącznie Rosjanie ${ }^{30}$. Urzędników polskiego pochodzenia i wyznania rzymskokatolickiego masowo zwalniano (tylko nielicznym Polakom udało się utrzymać posady - pozostawiano osoby o „nieposzlakowanej reputacji”, oraz niższych urzędników kancelaryjnych). Wymiana kadrowa miała, obok ukarania Polaków za powstanie, inne uwarunkowania. Po reformie uwłaszczeniowej w Cesarstwie Rosyjskim ogromna rzesza ludzi pozbawionych dochodów zwróciła się ku służbie w administracji. Około trzech tysięcy Rosjan oczekiwało wakatów na urzędniczych stanowiskach, podejmując pracę jako służba pomocnicza (bez wynagrodzenia) ${ }^{31}$. Murawjow wiele wakatów zagwarantował pozbywając się Polaków. Rząd rosyjski zachęcał urzędników z Rosji centralnej do podjęcia pracy w „Kraju Zachodnim” przede wszystkim ulgową sprzedażą dóbr ziemskich, skonfiskowanych po powstaniu, dodatkami do pensji i innymi korzyściami materialnymi oraz obietnicami przyspieszenia kariery ${ }^{32}$. Przybyłemu po powstaniu do Wilna Hipolitowi Korwin-Milewskiemu właśnie zmiana narodowości „biuralistów" szczególnie rzuciła się w oczy:

\begin{abstract}
Miasto już było nie do poznania - przedewszystkiem co do personelu urzędniczego. W ciagu kilku miesięcy Murawjew zdązyt, za wyjątkiem biednych „wolno-najemnych” kopistów bioracych po trzy ruble na miesiąc plus łapóweczki,zamienić wszystkich urzędników Polaków, na jaka szuję; każdy się domyśli; dobra połowa „nihilistów”. To wszystko przyjeżdżało całemi pociagami, otrzymywato $w$ kancelarii spis wakujacych urzędów $i$ wiedziele rano zapetniało ogromna sale pałacu generat-gubernatorskiego. Satrapa w kilku stowach ze spisem $w$ ręku rozdawat mannę ${ }^{33}$.
\end{abstract}

Świadka tamtego czasu uderzał przede wszystkim sposób, w jaki Rosjanie otrzymywali nominacje na posady urzędnicze - nie liczyło się ani wykształcenie, ani doświadczenie, wystarczała rosyjska narodowość. Zwracał uwagę również na specyfikę zapełniających urzędy - często były to persony o wątpliwej konduicie i burzliwej przeszłości zawodowej, których z powodu braku kompetencji lub dyskusyjnych postaw etycznych pozbywano się z głębi Rosji.

${ }^{30}$ R. Jurkowski, Ziemiaństwo polskie Kresów Pólnocno-Wschodnich, Warszawa 2001, s. 435.

${ }^{31}$ Л.Е. Шепелев, $d z$. cyt., s. 123.

32 Полное собрание законов..., 2-е собрание, t. 39, 1864 r., $\mathrm{nr}$ 40582, 40655, 40806, 41035, 41236.

${ }^{33}$ H. Korwin-Milewski, Siedemdziesiąt lat wspomnień (1855-1925), Poznań 1930, s. 52. 
Analiza Pamiatnych kniżek wilenskoj guberni, które wychodziły od 1845 roku ukazuje, że w do powstania styczniowego większość urzędników nawet w kancelarii generał-gubernatora - stanowili Polacy. Obsada kancelarii generał - gubernatora wileńskiego - Fiodora Mirkowicza w 1845 roku przedstawia się następująco. Szefem kancelarii był Józef Korecki, głównym sekretarzem - Aleksander Chmieliński, na stanowisku sekretarzy znajdujemy Aleksandra Budkiewicza, Dawida Bazarewskiego i Aleksandra Karpińskiego, na stanowisku pomocników sekretarza zatrudniono Karola Orzechowskiego, Kazimierza Majskiego i Szymona Atraszkiewicza, pomocnicy etatowi to: Ksawery Stankiewicz, Ludwik Ankiewicz i Michał Romański, na etacie pisarza i skarbnika pracował Jan Szempliński, urzędnikami od specjalnych poleceń byli: Edgar Białocki, Florian Rzewuski, Iwan Żyliński, Piotr Korecki, Szymon Golicow i Piotr Czaniecki ${ }^{34}$. Właściwie znajdujemy tu tylko jedno rosyjskie nazwisko. Ale kancelaria generał gubernatora Aleksandra Potapowa w 1873 roku jest już zupełnie zdominowana przez Rosjan - na jej czele stał Mikołaj Rubcow, jego zastępcami byli Mikołaj Makarow, Mikołaj Nikotin, Wasyl Ryżkow, Iwan Podgorodnikow, niższe stanowiska urzędnicze również zajmowali Rosjanie ${ }^{35}$. Według zestawień opracowanych przez białoruskiego historyka Siarhieja Tokcia na 3400 urzędników rangowych zatrudnionych w służbie cywilnej pięciu guberni północno-zachodnich (wileńskiej, witebskiej, grodzieńskiej, mińskiej, mohylewskiej) w roku 1868, 2591 urzędników było wyznania prawosławnego (76,2\%), 571 wyznania rzymskokatolickiego $(16,8 \%)$, 153 osoby były protestantami (4,5\%), a 75 muzułmanami $(2,2)^{36}$. Roman Jurkowski podaje, że w latach $1863-1865 \mathrm{w}$ pięciu guberniach zachodnich przyjęto do służby 4619 nowych urzędników niepolskiego pochodzenia i niekatolickiej konfesji ${ }^{37}$. Znakomita większość urzędników/Polaków/katolików po powstaniu styczniowym straciła swoje etaty. Wstrzymano rekrutację na posady urzędnicze dla Polaków ${ }^{38}$. Jedynie urzędnicy, którzy w okresie międzypowstaniowym wyjechali w głąb Rosji, czuli się na swoich stanowiskach w miarę stabilnie. Najczęściej zrywali oni kontakty z rodzinami pozostałymi na ziemiach litewsko-białoruskich, by nie znaleźć się w gronie podejrzanych o sprzyjanie powstańcom. Polscy urzędnicy „kresowi”, nawet Ci znani ze swojej sumienności, wieloletni pracownicy jednej kancelarii byli masowo zwalniani, pozostając niejednokrotnie z całymi rodzinami bez środków do życia. Część ze zwolnionych zostało przesiedlonych w głąb Rosji. Wielu z nich szukało możliwości zarobkowania zmieniając zawód. W skrajnie trudnych warunkach starali się oni przeczekać trudny okres.

${ }^{34}$ Памятная книжка Виленской губернии на 1845 г., Wilno 1845, s. 12-16.

${ }^{35}$ Памятная книжка Виленской губернии на 1873 г., Wilno 1873, s. 4-6.

${ }^{36} \mathrm{~S}$. Tokć, Dziarżalny aparat caryzmu u Biełarusi y 30-60 h gg. XIX st., Dysertacja doktorska obroniona na Akademii Nauk Białorusi w Mińsku w 1997 r., s. 145.

${ }^{37}$ R. Jurkowski, dz. cyt., s. 435-436.

${ }^{38}$ Podobna sytuacja miała miejsce również w Królestwie Polskim, por.: S. Wiech, Między pragmatyzmem a serwilizmem..., s. 199-210. 
Akcja rusyfikacyjna aparatu administracyjnego nie przyniosła długofalowych efektów. Główną przyczynę niemożności całkowitej wymiany urzędników na rosyjskich należy upatrywać w niskich kwalifikacjach skuszonych specjalnymi dodatkami i gratyfikacjami czynowników z centralnej Rosji. Rządni awansów i nagród przybysze nie przedstawiali wysokich kompetencji, a ich podejście do sprawowania urzędu również pozostawiało wiele do życzenia. Kolejni gubernatorzy nie mogąc poradzić sobie z utrzymaniem sprawnej administracji decydowali się (aczkolwiek niechętnie) na przyjmowanie Polaków. U schyłku XIX stulecia większość urzędników ponownie stanowiły osoby wyznania rzymsko-katolickiego. Generał-gubernator wileński Witalis Trocki pisał w raporcie do cara, że pośród urzędników miejskich tylko 18,6\% stanowią prawosławni, reszta to katolicy ${ }^{39}$. Rusyfikacja administracji „Kraju Zachodniego” poniosła więc fiasko. Należy jednak podkreślić, że „kulturkampf” w wydaniu rosyjskim dotknął tę grupę tak samo dotkliwie jak duchowieństwo i ziemiaństwo.

Wielu pracowników administracji cywilnej polskiego pochodzenia w guberniach północno-zachodnich zdecydowanie odróżniała się od urzędniczej braci Rosjan - przede wszystkim stosunkiem do sprawowanego urzędu. Istniała grupa polskich urzędników, w których kiełkowało pozytywistyczne przekonanie o użyteczności społecznej piastowania administracyjnego stanowiska. Dla części służba cywilna była równoznaczna ze służbą społeczeństwu. Ci często doznawali gorzkiego zawodu - system prawny państwa zaborczego, zwłaszcza po zrywach narodowo-wyzwoleńczych, był wobec społeczeństwa represyjny. Dyrektywy otrzymywane od władz, które godziły w dobro podwładnych, skutkowały wewnętrznym rozdarciem. Konflikt sumienia wyraźnie zarysował się w kilku biografiach ${ }^{40}$. Zdarzały się przypadki porzucania pracy w skutek braku akceptacji dla postanowień władzy zwierzchniej. Niektórzy przez wiele lat wykazywali zewnętrzną akceptację, poddając się wymogom formalnym sprawowanego urzędu, a jednocześnie zachowywali niezależność myślenia, czasami nawet wykorzystując rangę i mundur do celów przeciwdziałania rusyfikacji ${ }^{41}$. Tak jak dla

${ }^{39}$ Cyt. za: R. Jurkowski, dz. cyt., s. 479.

${ }^{40}$ M. Korybut-Marciniak, Wilno-Nowogród-Petersburg-Warszawa. Życie carskiego urzędnika, [w:] Litwa i jej sąsiedzi w relacjach wzajemnych (XVII-XIX w.), red. I. Janicka, A. Kołodziejczyk, Olsztyn-Gdańsk 2014, s. 113-124; taż, Na stużbie w Petersburgu - stolica carów w oczach Artura Dolińskiego, „Echa Przeszłości” 2014, t. XV, s. 109-126; taż, Stanisław i Artur Dolińscy-rosyjscy urzędnicy. Problem tożsamości Polaków w obcej stużbie, [w:] Między irredentą a kolaboracją. Ugoda, lojalizm, legalizm. „Dusza urzędnika” - ludzie i ich kariery, red. A Szmyt, Olsztyn 2015, s. 123-142; taż, Kariery urzędnicze mieszkańców ziem litewsko-białoruskich w aparacie administracyjnym Cesarstwa Rosyjskiego w XIX wieku, [w:] Dzieje biurokracji, t. 6, red. T. Bykowa, A. Górak, G. Smyk, Lublin 2016, s. 365-409.

${ }^{41}$ Przykład stanowi Antoni Łazarowicz (1817-1904) - wieloletni pracownik Wileńskiej Izby Skarbowej i Zarządu Dóbr Państwa, który systematycznie pisał i publikował (własnym sumptem) modlitewniki, elementarze i poezję $\mathrm{w}$ języku polskim. Był zagorzałym zbieraczem pamiątek historycznych dotyczących Wilna. Inwentaryzował też wileńskie cmentarze. Był jedynym pisarzem, 
ziemian kresowych ostoją polskości stawał się majątek (dwór), tak dla urzędnika był to krąg rodzinny. W wielu rodzinach urzędniczych kultywowano narodowe tradycje, w czasie spotkań w najbliższym gronie śpiewano polskie pieśni, używano języka polskiego w codziennych kontaktach i korespondencji. Z pewnością było również wielu takich, którzy „na biurowej posadzie” widzieli możliwość łatwego zarobku. Korupcja pośród „biuralistów” w carskiej Rosji była przysłowiowa i wielu polskich urzędników dorównywało pomysłowością na zdobycie kubanów swoim rosyjskim kolegom. Większość Rosjan służących w guberniach zachodnich za główny cel stawiała sobie szybki zysk i równie szybką karierę. „Niepokorne” społeczeństwo ziem litewsko-białoruskich było poddawane przez nich metodycznemu wyzyskowi.

Polacy w służbie cywilnej Rosji to grupa, która wymaga głębszego zbadania, wyjścia również poza urzędowe akta osobowe pozostające w kancelariach i wniknięcia w ich życie rodzinne, prywatne, religijne (to zadanie niełatwe, ponieważ materiałów źródłowych ilustrujących tę stronę urzędniczego życia zachowało się niewiele). Pobieżna ocena tej grupy plasuje ją w rzędzie serwilistów, których oczywiście nie brakowało. Przybliżenie soczewki ku poszczególnym życiorysom rodzi wątpliwości, co do bezwzględnej uległości, ukazuje wewnętrzną dychotomię postaci, które w obcej służbie widziały jedyny sposób na życie. Wielu z nich tracąc nadzieję na zmianę polityczną ziem wcielonych do Rosji starało się z jednej strony odnaleźć miejsce w zaborowej rzeczywistości, z drugiej - nie zatracić swojej narodowej tożsamości poprzez przywiązanie do konfesji, języka polskiego używanego wyłącznie w kontaktach z najbliższymi, publikacje w polskich czasopismach. Wielu wierzyło, że ich „biurowe posady” mogą przysłużyć się polskiemu społeczeństwu. Szereg z nich stawało się pozytywistami z podciętymi skrzydłami - gdy realia służby cywilnej oraz represyjność systemu wiązały im ręce. Z pewnością urzędnicy carscy polskiego pochodzenia nie stanowili monolitu. Jest to grupa, której należałoby poświęcić wnikliwe studia nie ulegając stereotypowemu myśleniu o „obcym mundurze”.

który po 1886 r. tworzył w Wilnie; zob. szerzej: A. Śnieżko, Łazarowicz (Łazarewicz) Antoni, [w:] Polski stownik biograficzny, t. 18, Wrocław-Warszawa-Kraków 1973, s. 286; A. Romanowski, Pozytywizm na Litwie. Polskie życie kulturalne na ziemiach litewsko-białorusko-inflanckich w latach 1864-1904, Kraków 2003, s. 203. 
Maria Korybut-Marciniak

\section{CONTRIBUTION TO THE RESEARCH OF SERVICE OF THE POLES FROM THE TERRITORY OF THE LITHUANIAN-BELARUSIAN CIVIL ADMINISTRATION IN THE RUSSIAN EMPIRE IN THE NINETEENTH CENTURY}

Community of Poles as civil servants in the public administration of Russian Empire on the Lithuanian-Belarusian territory in the nineteenth century is a white stain in Polish historiography. A cursory evaluation of the group might show servility of the group but insightful look at individual biographies raises doubts of its absolute submission. Many of the officials, losing their hope for political change in the territory annexed to Russia, tried to find their place in the reality after partition on the one hand, and not lose their national identity on the other. Certainly, tsarist's officials of Polish origin were not a monolith. This is a group, which could be devoted to in-depth studies without stereotypical thinking about ,a foreign uniform”.

Słowa kluczowe: urzędnicy, XIX wiek, inteligencja, administracja, biurokracja, służba cywilna, Rosja, gubernie północno-zachodnie.

Keywords: officials, nineteenth century, intelligence, administration, bureaucracy, civil service, Russia, northwestern governorates

\section{BIBLIOGRAFIA}

\section{Źródła}

Lietuvos Valstybės Istorijos Archyvas, f. 378, inw. 131.

Памятная книюка Виленской губернии на 1845 г., Wilno 1845

Памятная книжка Виленской губернии на 1873 2., Wilno 1873.

Полное собрание законов Российской Империи, 2-е собрание

\section{Opracowania}

Beauvois D., Inteligencja bez wyjścia (1803-1832), [w:] Inteligencja polska pod zaborami, red. R. Czapulis-Rastenis, Warszawa 1978.

Beauvois D., Szkolnictwo polskie na ziemiach litewsko-ruskich 1803-1832, t. 1, Uniwersytet Wileński, Lublin 1991.

Caban W., Inteligencja prowincjonalna wobec walki o niepodległość $w$ XIX wieku na przykładzie urzędników administracji państwowej Guberni Radomskiej, [w:] Polska w XIX i XX wieku, Społeczeństwo i gospodarka, red. W. Caban, J. Szczepański, Kielce 2013.

Caban W., Urzędnicy administracji państwowej a powstanie styczniowe (na przykładzie guberni radomskiej), [w:] Inteligencja polska XIX i XX wieku, t. 5, red. R. Czepulis-Rastenis, Warszawa 1987.

Chwalba A., Imperium korupcji w Rosji i Królestwie Polskim w latach 1861-1917, Warszawa 2001.

Chwalba A., Polacy w stużbie Moskali, Warszawa 1999.

Cichoń P., Korpus urzędniczy w myśli administracyjnej Księstwa Warszawskiego 1807-1815, „Krakowskie Studia z Historii Państwa i Prawa" 2004.

Jurkowski R., Ziemiaństwo polskie Kresów Pótnocno-Wschodnich, Warszawa 2001. 
Knopp T., Prefekci Księstwa Warszawskiego. Przyczynek do portretu zbiorowego, „Studia Historyczne” 2012, R. 55 , z. $3-4$.

Koranyi K., Powszechna historia państwa i prawa, Warszawa 1966, t. III.

Korwin-Milewski H., Siedemdziesiąt lat wspomnień (1855-1925), Poznań 1930.

Korybut-Marciniak M., Kariery urzędnicze mieszkańców ziem litewsko-białoruskich w aparacie administracyjnym Cesarstwa Rosyjskiego w XIX wieku, [w:] Dzieje biurokracji, t. VI, red. T. Bykowa, A. Górak, G. Smyk, Lublin 2016.

Korybut-Marciniak M., Na stużbie w Petersburgu - stolica carów w oczach Artura Dolińskiego, „Echa Przeszłości” 2014, t. XV.

Korybut-Marciniak M., Stanistaw i Artur Dolińscy-rosyjscy urzędnicy. Problem tożsamości Polaków w obcej stużbie, [w:] Między irredenta a kolaboracja. Ugoda, lojalizm, legalizm. „Dusza urzędnika” - ludzie i ich kariery, red. A. Szmyt, Olsztyn 2015.

Korybut-Marciniak M., Wilno-Nowogród-Petersburg-Warszawa. Życie carskiego urzędnika, [w:] Litwa i jej sąsiedzi w relacjach wzajemnych (XVII-XIX w.), red. I. Janicka, A. Kołodziejczyk, Olsztyn-Gdańsk 2014.

Latawiec K., Naczelnicy powiatów guberni lubelskiej w latach 1867-1915. Próba charakterystyki grupy, „Annales UMCS”, sectio F, vol. LVIII, 2003.

Latawiec K., Obsada personalna chetmskiego zarzadu powiatowego w latach 1867-1915, „Rocznik Chełmski”, t. 10, 2006.

Latawiec K., Urzędnicy pochodzacy z guberni białoruskich w korpusie cywilnej administracji ogólnej Królestwa Polskiego na przełomie XIX i XX w. Przyczynek do badań nad inteligencja urzędnicza w imperium rosyjskim, [w:] Дызяспара. Культуралогія. Гісторыя, пад рэд. А. Мальдзіса, А. Смаленчука, Минск 2006.

Marszałek P. K., Gubernatorzy wojskowi w systemie polskiej administracji początków XIX wieku, „Czasopismo Prawno-Historyczne" 2012, T. 64, z. 1.

Mickiewicz A., Dziady, t. II, Paryż 1844.

Między irredenta a kolaboracja. Ugoda, lojalizm i legalizm. „Dusza urzędnika” - zewnętrzna akceptacja $i$ wewnętrzna niezgoda?, red. N. Kasparek, M. Klempert, Olsztyn 2015.

Między irredenta a kolaboracją. Ukoda, lojalizm, legalizm. „Dusza urzędnika” - ludzie i ich kariery, red. A. Szmyt, Olsztyn 2015.

Osiecka M., Urzędnicy Komisji Rządowych Królestwa Polskiego 1815-1867, „Miscellanea Historico-Archivistica" 2014, t. 21.

Romanowski A., Pozytywizm na Litwie. Polskie życie kulturalne na ziemiach litewsko-białorusko-inflanckich w latach 1864-1904, Kraków 2003.

Rostocki W., Korpus w gęsie pióra uzbrojony. Urzędnicy warszawscy, ich życie i praca w Księstwie Warszawskim i Królestwie Polskim do roku 1831, Warszawa 1972.

Sikorska-Kulesza J., Deklasacja drobnej szlachty na Litwie i Białorusi w XIX wieku, Warszawa 1995.

Smyk G., Administracja publiczna Królestwa Polskiego w latach 1864-1915, Lublin 2011.

Smyk G., Zasady funkcjonowania rosyjskiego modelu biurokratycznego w Królestwie Polskim po powstaniu styczniowym, „Studia z Dziejów Państwa i Prawa Polskiego” 2006, nr 2.

Stolzman M., Nigdy od ciebie miasto... Dzieje kultury wileńskiej lat międzypowstaniowych (1832-1863), Olsztyn 1987.

Suma T., Urzędnicy poczty Królestwa Polskiego w latach 1815-1866: próba charakterystyki zbiorowości, Warszawa 2008.

Szczepański J., Urzędnicy administracji państwowej Królestwa Polskiego w latach 1815-1866, Kielce 2015.

Śliwowska W., Mikolaj I i jego czasy (1825-1856), Warszawa 1865.

Tokć S., Dziarżalny aparat caryzmu u Biełarusi y 30-60 h gg. XIX st., Dysertacja doktorska obroniona na Akademii Nauk Białorusi w Mińsku w 1997 r. 
Wiech S., Lustracje urzędników administracji państwowej Królestwa Polskiego w latach 1866-1873, [w:] Między irredenta a kolaboracją. Polacy w czas zaborów wobec obcych władz i systemów politycznych, red. S. Kalembka, N. Kasparek, Olsztyn 2001.

Wiech S., Między pragmatyzmem a serwilizmem. Charakterystyka postaw i zachowań urzędników Królestwa Polskiego po upadku powstania styczniowego w ocenie carskiej policji politycznej, [w:] Między irredenta a kolaboracja. Postawy spoleczeństwa polskiego w latach niewoli - „W obcym mundurze”, red. L. Michalska-Bracha i M. Korybut-Marciniak, Warszawa 2013.

Wiech S., Urząd generat-gubernatora w Rosji i w Królestwie Polskim, „Czasopismo Prawno-Historyczne”, t. 59, 2007, Z. 1 .

Wiech S., Warszawscy generałowie-gubernatorzy o sytuacji społeczno-politycznej Królestwa Polskiego. Raporty Albiedynskiego i Szuwałowa z lat 1881 i 1896, oprac. S. Wiech, Kielce 2007.

Zasztowt L., Kresy 1832-1864, Szkolnictwo polskie na ziemiach litewsko-ruskich dawnej Rzeczpospolitej, Warszawa 1997.

Zieliński Z., Wyżsi urzędnicy pruskiej administracji prowincjonalnej w Poznańskiem 1871-1918, Poznań 2014.

Żywicki J., Urzędnicy - architekci, budowniczowie, inżynierowie cywilni...: ludzie architektury i budownictwa w województwie lubelskim oraz guberni lubelskiej w Królestwie Polskim w latach 1815-1915, Lublin 2010.

Горизонтов Л. Е., Служить или не служить империи? Поляки в Pоссии ХІХ в., [w:] Rosyjsko-polskie kontakty językowe, literackie i kulturalne, red. W. Choriew, M. Wołos, Moskwa 2011.

Горизонтов Л. Е., Парадоксы имперской политики: поляки в России и русские в Польше, Москва 1999.

Шепелев Л.Е, Чиновный мир России ХVII - иачало ХХ в., Sankt Petersburg 1999. 